\title{
越流津波に対する従来型式の海岸堤防の 被災メカニズム
}

\author{
松島 健一 1 三島 尚人 2 ・桐 博英 3 ・中 達雄 4 \\ $1,2,3,4$ 正会員 国立研究開発法人 農研機構 農村工学研究所 \\ （干305-8201 茨城県つくば市観音台2-1-6） \\ E-mail:kenichim@affrc.go.jp
}

\begin{abstract}
東北地方太平洋沖地震津波による三面張り海岸堤防の被災原因を解明するため，地震力の影響によって被 覆コンクリートの目地部の遮水性が低下した条件と, 遮水性が保持された条件を模擬した堤防モデルを対 象として，越流水理実験を実施した。その結果，目地部の遮水性が低下した場合，比較的小規模な越流で も目地部に越流水が浸入し，泥濘化した背面土の土圧によって裏法コンクリートが押し出された。一方, 目地部の遮水性が保持された場合でも，越流水深 $5.0 \mathrm{~m}$ 程度を上回ると，揚力によって裏法コンクリートが 引き剥がされた. 以上のことから, 粘り強さを向上させるためには, 地震等に強い被覆構造に加えて, 被 覆工の引き剥がれを防止するとともに，被覆工背面の盛土材が泥濘化しない工夫が必要であることがわか った.
\end{abstract}

Key Words : coastal dike, overflow, tsunami, failure mechanism

\section{1. まえがき}

過去の高潮災害等を契機に，我が国では高潮や高波の 際に生じる多少の越波に対して盛土材の流失を防止する ため，堤防天端と裏法面をコンクリートで被覆する三面 張り堤防が採用されてきた. しかし，従来式堤防は大規 模な越流に対応して設計されたものではない1).今般の 東北地方太平洋沖地震津波では，堤防上を越流した津波 によって多くの海岸堤防に著しい損傷や完全な崩壊が生 じた2).これを受けて，中央防災会議の東北地方太平洋 沖地震を教訓とした地震・津波対策に関する専門調查会 報告3)では，「設計対象の津波高を超えた場合でも施設 の効果が粘り強く発揮できるような構造物の技術開発を 進め，整備していくことが必要である」とされた.

本研究では，上記の防災・減災に対する社会的要請を 受け，今般の津波で被災した海岸堤防の構造的弱点を抽
出・改善することを目的として，三面張り海岸堤防を対 象とした越流水理実験を実施し, 破堤原因の究明と対策 について検討を行った.

\section{2. 実験方法}

実験水路は図-1に示すように幅 $2.0 \mathrm{~m}$ ，高さ $3.0 \mathrm{~m} ，$ 長さ $63.0 \mathrm{~m}$ ，沖側にゲート引き上げ装置を有する断面二次元 水路を用いた。水路床から $1 / 6.9$ 勾配の斜面を取付け，高

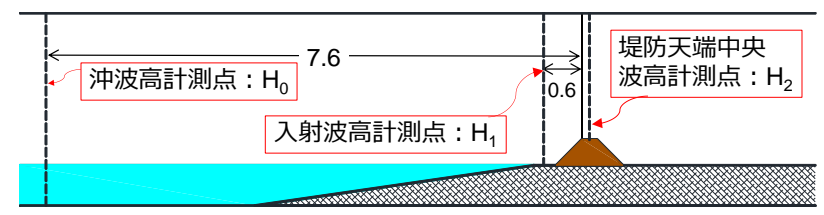

(a) 堤防周辺拡大図（波高計測点）

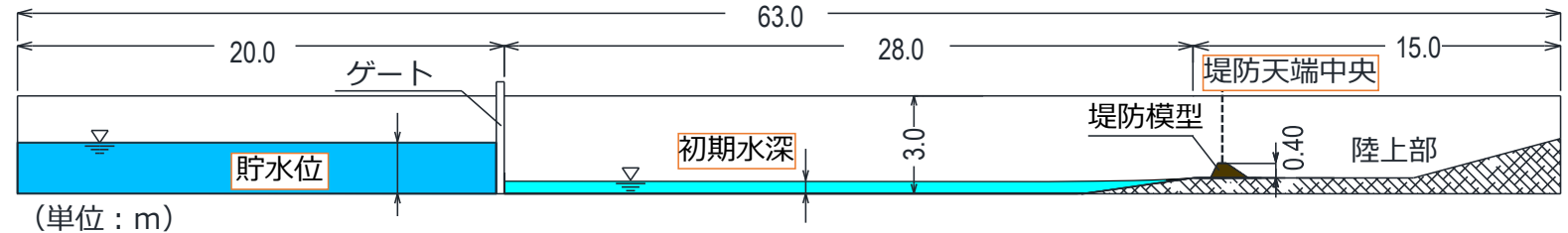

(b) 実験水路全体図

図-1 ゲート開閉式の大型断面二次元水路 


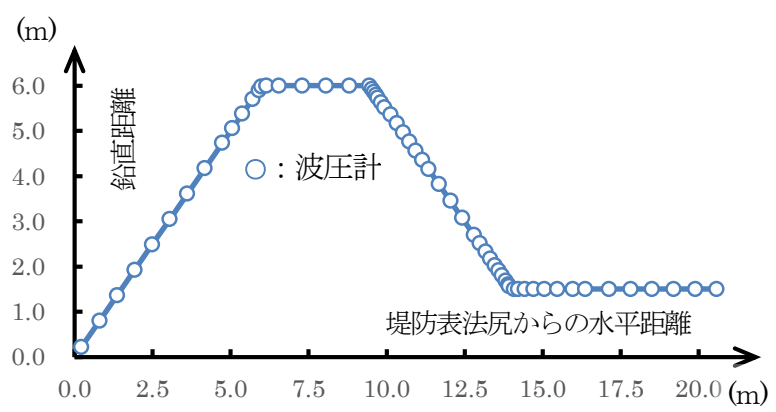

図-2＼cjkstart波圧センサー配置図(現地換算)

さ0.63mの位置に堤防模型を設置した.ゲート上流に貯 水することで初期水位との水位差 $\Delta h$ を設け，ゲートを 一気に引き上げることによって最大周期 20 秒程度（現地 換算で約80秒）の段波を発生させることがでさる．波高 及び流速はそれぞれ容量式波高計とプロペラ式流速計を 用いて，堤防前浜部及び堤防天端中央部の2ヶ所で計測 した．流速計はそれぞれ初期水面，堤頂から高さ $75.0 \mathrm{~cm}$ の位置に設置した（現地換算）。波圧は小型圧力センサ 一を用い，図-2に示すように表法面のみで17箇所，合計 60箇所に設置した．計測間隔は衝撃的な波力を計測する ため，1.0msecに設定した4)。なお，本模型実験ではフル ードの相似則に従うものと仮定した。

\section{(1) 堤防モデル}

写真-1に水理実験に用いた三面張り堤防モデルを示す 模型縮尺は1/15である，堤高6.0m，天端幅 $3.5 \mathrm{~m} ，$ 表法・ 裹法勾配1: 1.0，表法コンクリート厚 $0.50 \mathrm{~m}$ ，天端及び裏 法コンクリート厚 $0.25 \mathrm{~m}$ である。地震等による影響を考 慮して目地部の遮水性が低下した目地劣化モデル及び者 水性が保持された目地健全モデルを設定した。目地材に はそれぞれ透水性スポンジと遮水性スポンジを用いた。

目地幅はともに約 $2.1 \mathrm{~cm}$ (現地換算值) である. 盛土は 鉾田砂（ $\mathrm{D}_{50}=0.103 \mathrm{~mm}, \mathrm{Fc}=33.9 \%, \mathrm{Uc}=26.0, \rho \mathrm{dmax}=$ $1.669 \mathrm{~g} / \mathrm{cm}^{3}, \mathrm{k}_{15}=3.30 \times 10^{-2} \mathrm{~m} / \mathrm{sec}$ ）を厚さ $0.30 \mathrm{~m} / 15=2.0 \mathrm{~cm}$ にな るように締固め度（標準プロクター） $\mathrm{Dc}=90 \%$ で転圧し た。国総研5において越流水によって裹法側の地盤が洗 堀されることが報告されている.このため，本実験では 裏法側の地盤をセメント改良土に置き換え，洗堀に伴う 根固め工の変位を防止して実験を行った。

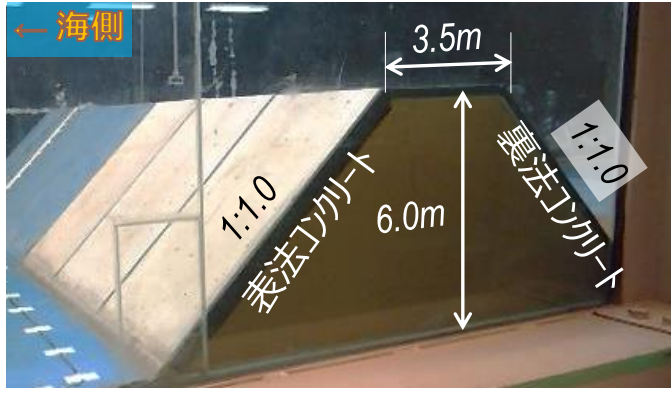

(a) 水路側壁のガラス面から見た状況

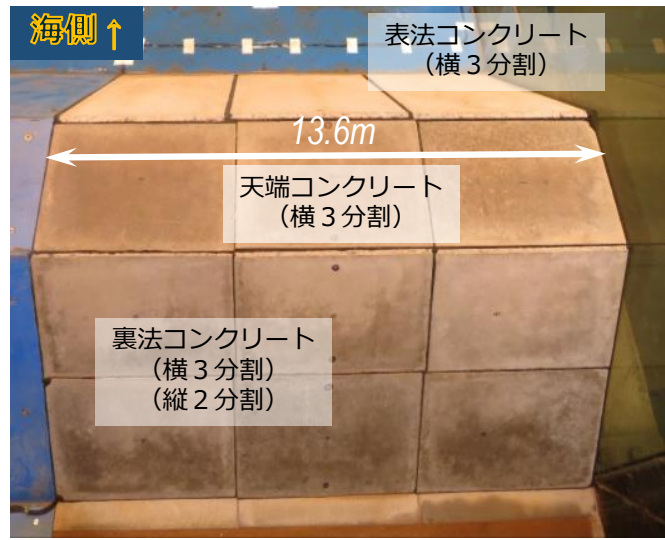

(b) 堤防天端上から見た状況

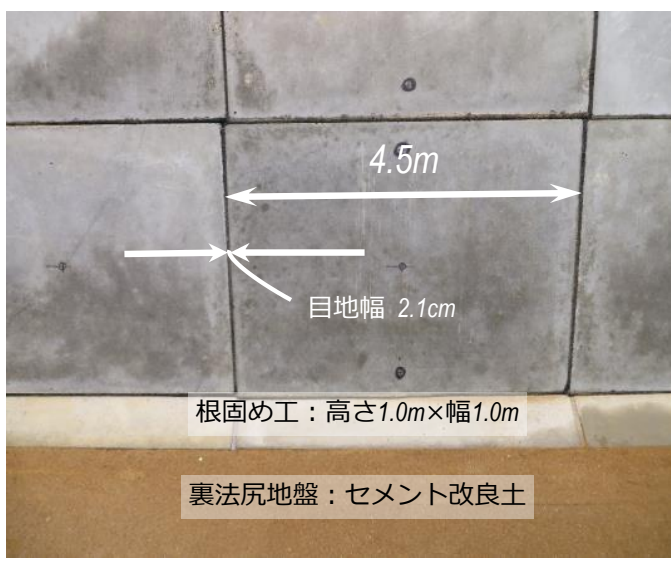

(c) 裏法尻から見た状況

写真-1 水理実験に用いた三面張り海岸堤防モデル

\section{(2) 入射条件}

表-1に本実験の入射条件及び実験結果の概要を示す. 砕波条件の詳細については松島らすを参照されたい. 図一 3に堤防への作用波力及び越流特性を示す。なお，堤防

表-1 入射条件及び実験結果の概要

\begin{tabular}{c|c|c|c|c|c|c}
\hline No & 初期水位 & 貯水位 & $\begin{array}{c}\mathrm{H}_{0} \text { における } \\
\text { 入射波高 }\end{array}$ & $\begin{array}{c}\mathrm{H}_{1} \text { における } \\
\text { 入射波高 }\end{array}$ & $\begin{array}{c}\text { 目地劣化 } \\
\text { モデル }\end{array}$ & $\begin{array}{c}\text { 目地健全 } \\
\text { モデル }\end{array}$ \\
\hline No.1 & $9.45 \mathrm{~m}$ & $16.2 \mathrm{~m}$ & $5.18 \mathrm{~m}$ & $3.84 \mathrm{~m}$ & 裏コン孕出し & 変化なし \\
\hline No.2 & $9.45 \mathrm{~m}$ & $17.7 \mathrm{~m}$ & $7.30 \mathrm{~m}$ & $6.85 \mathrm{~m}$ & 崩壊 & 変化なし \\
\hline No.3 & $9.45 \mathrm{~m}$ & $19.2 \mathrm{~m}$ & $8.20 \mathrm{~m}$ & $7.54 \mathrm{~m}$ & 実施せず & 崩壊 \\
\hline
\end{tabular}

(※堤防未設置条件における波高である.) 
表法面への作用波力は，各波圧計で計測した波圧分布か ら求めた。図-3(a)中のNo.1及びNo.2は堤防直前で砕波す るため，No. 3の砕波後の波よりも衝撃的な波力が発生 する，ただし，衝撃的波力の作用時間は極めて短く3.0

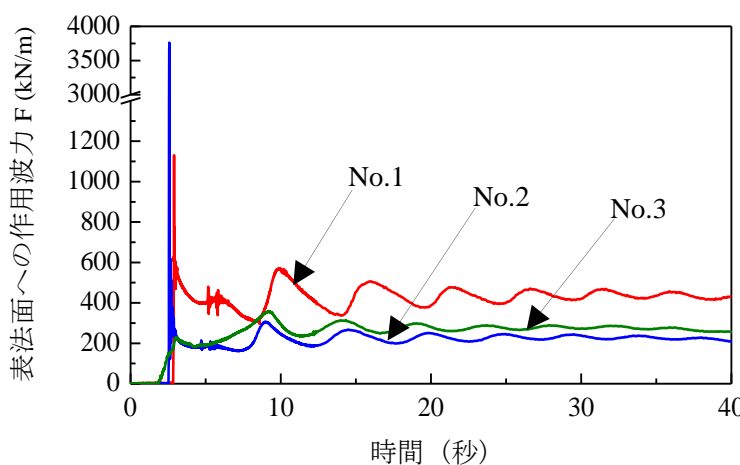

(a) 堤防への作用波力

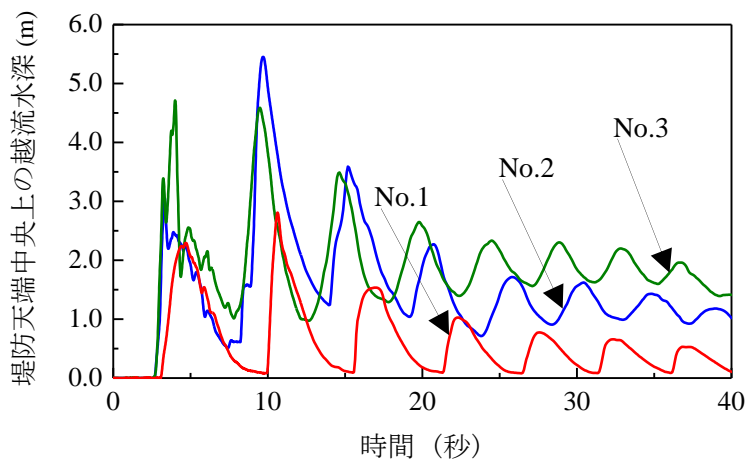

(b) 堤防天端中央上の越流水深

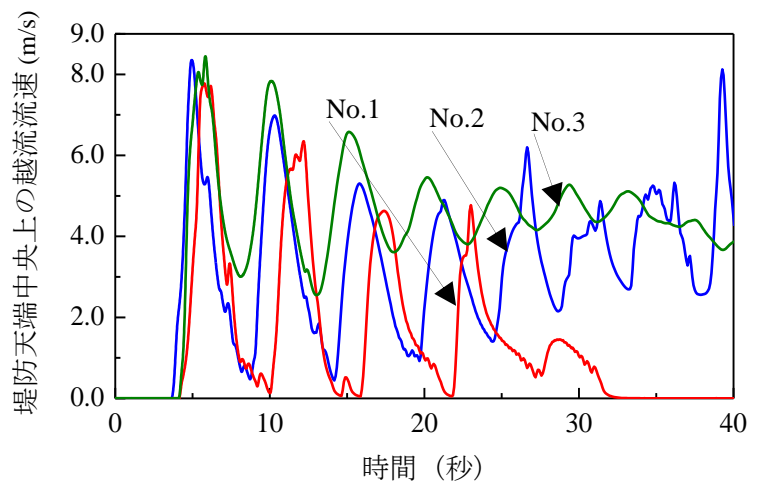

(c) 堤防天端中央上の越流流速

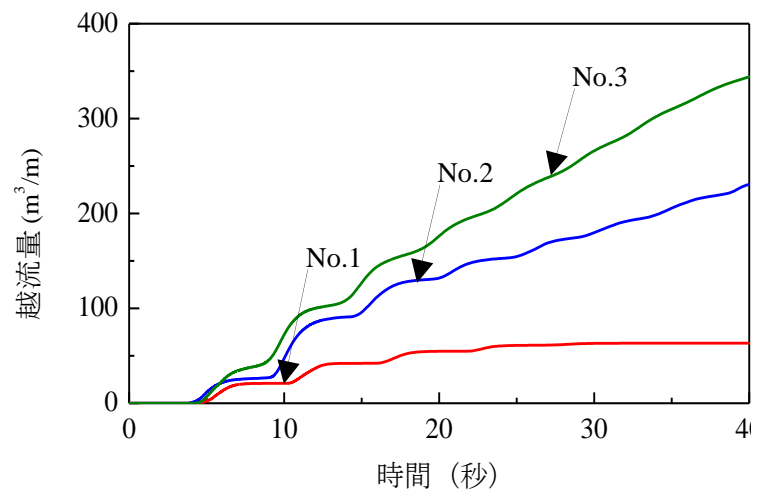

(d) 堤防上の越流量

図-3 堤防への作用波力と越流特性
〜8.0msec程度である．衝突直後はいずれのケース(No.1 〜No.3) も表法面に沿つて越波が発生し，堤防背後に越 波が衝突した。堤防に衝突した波は反作用力を受けて前 浜へ一旦引き戻され，反射波と入射波の連続的な到達に よって著しい水位上昇が生じた。この重複波が再び堤防 に押し寄せた際に，図-3(a)中に示すように堤防に重複波 力が作用し，図-3(b)，(c)中の堤防上の越流水深及び越流 流速が再び増加に転じた，その後，反射波の影響によっ て上記の変動が繰り返された。 やがて定常的な流れに近 づくと持続波力が作用した。衝突波力を除けば，図-3(a), (d)に見られるように堤防表法面への作用波力及び堤防 上の越流量は，No. 3，No. 2，No. 1の順に大きく，継続 的に波圧が作用した. 堤防天端中央上のフルード数を見 ると，越波分を除けば，およそ0.9〜 1.1の範囲にあり， 堤防天端上で常流から射流に変化していた。

以上のことから，砕波条件の違いによって衝突波力の 大きさが異なるが，衝突以降の流況及び波力に関する一 連の変化は，同様な傾向であることがわかった．なお， 本実験では，段波衝突から持続波に移行する過程を再現 しているが，実際の津波よりも周期も短く，複数の段波 の影響については考慮されていない.

\section{3. 実験結果}

\section{（1） 遮水性が低下した目地劣化モデル}

目地劣化モデルでは，No. 1の段波が作用している最 中には大きな変状が見られなかったが，越流終了後しば らくして，泥濘化した盛土材が裏法コンクリートと根固 め工の間から吹き出し，写真-2に示すように裏法コンク リートが押し出された，堤防越流中は目地部を通じて裏 法コンクリート背面に越流水が浸入するが，越流水がカ ウンターウェイトとして作用するため，裏法コンクリー

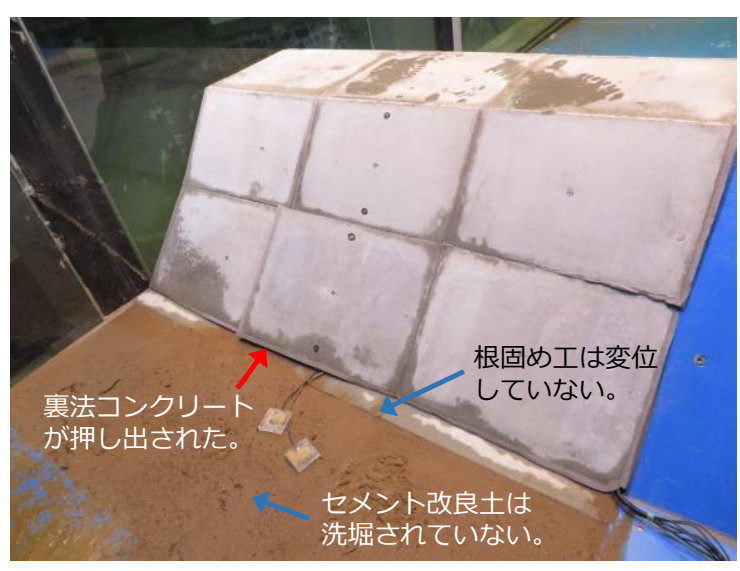

写真-2 目地劣化モデルにおける裏法コンクリート の変状 
トが押さえつけられた状態になっている。しかしながら， 越流水深が減少する過程になると, 越流水によるカウン

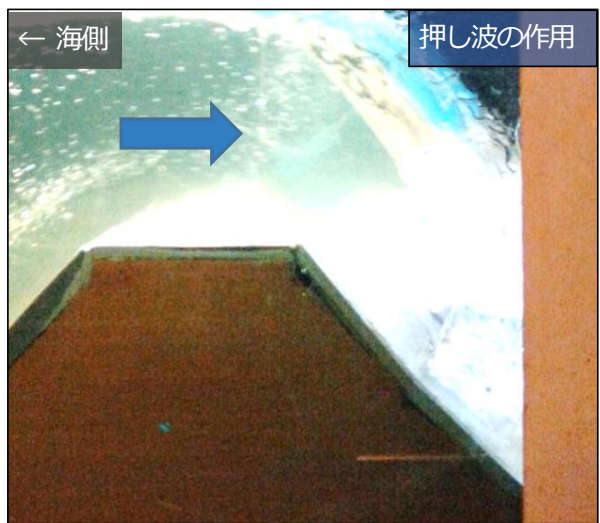

(a) 越流直後( 0 秒後)

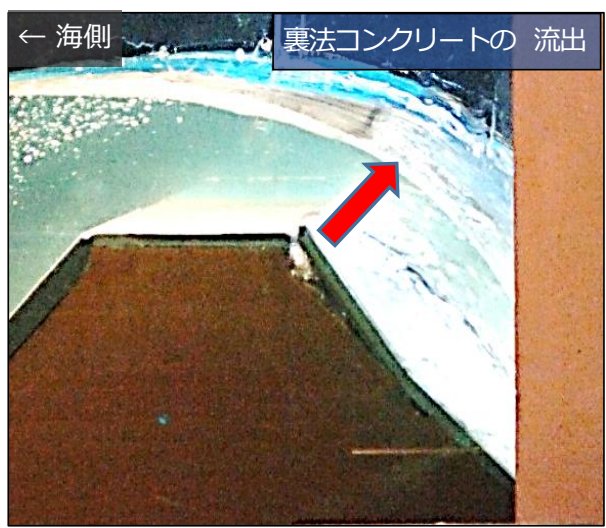

(b) 約 20 秒後

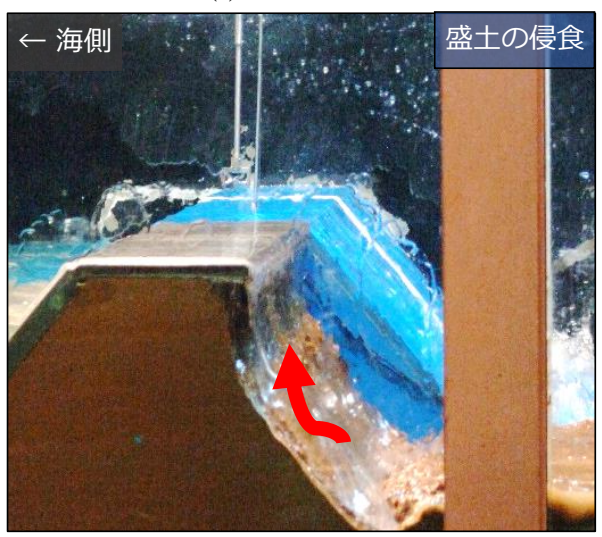

(c) 約 31 秒後

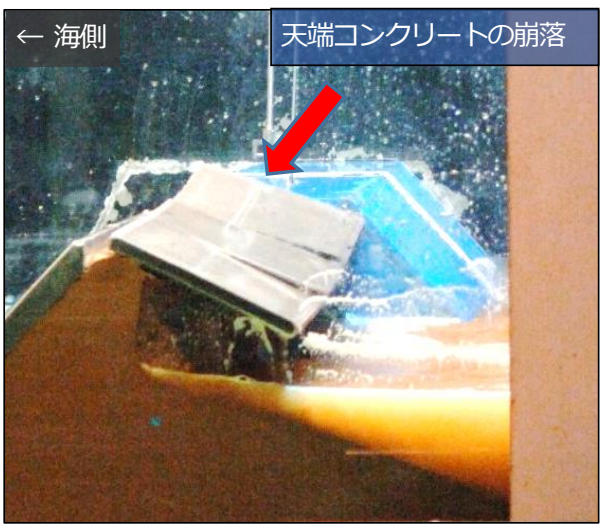

(d) 約 18 分後

写真-3 目地劣化モデルにおける被災過程
ターウェイトの効果が徐々に低下寸る，その結果，越流 終了後に，裏法コンクリート背面に残留した泥圧によっ て押し出されたものと考えられる。したがって，上記の 崩壊現象は，裏法コンクリート背面に流入した越流水が 引き金であり，目地部の遮水性に問題があったと言える。

さらに上記の損傷を受けた状態で，No. 2の段波を作 用させたところ，写真-3の被災過程に示寸ように堤防裏 側は裏法コンクリート間の隙間に越流水が流れ込み, 越 流開始から20秒後に裏法コンクリートが一斉に押し流さ れた，堤防裏側の盛土材は露出し，陸側に溜まった貯留 水による波浪によって盛土の侵食が進行した．約18分後 には堤体断面の約 2 まで侵食が進み，天端コンクリー トが崩落した．写真-4に被覆コンクリートを取り除いた 状況をみると，堤防裏法側の盛土に侵食が集中していた が，裏法尻の地盤はセメント改良を施すことで洗堀が防 止されており，根固め工の変状はまったく見られなかっ た. また堤防表側も変状も見られなかった.

\section{（2）遮水性を保持した健全目地モデル}

目地部の遮水性を確保することで，堤体内部一の越流 水の流入が阻止され，No.1及びNo. 2の段波に対して堤 防の損傷は生じなかった。一方，No. 3の段波を作用さ せた段階で，写真-5に示すように越流開始から約 9 秒後 に裏法肩コンクリートが引き剥がされた。このとき裏法

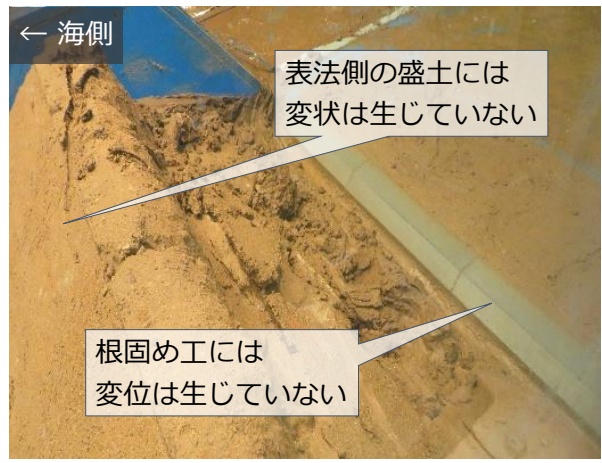

写真-4 被覆コンクリートを取り除いた状態

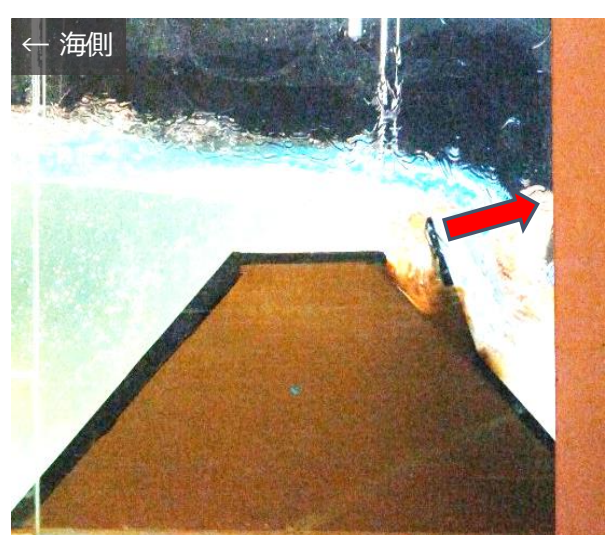

写真-5 目地健全モデルにおける 裹法コンクリートの引き剥がれ現象 
肩付近に設置した波圧計には，40〜 45kPa程度の負圧が 発生していた. この圧力は越流水深が深く, 高速の越流 水が通過する際に，遠心力の働きによって生じるもので

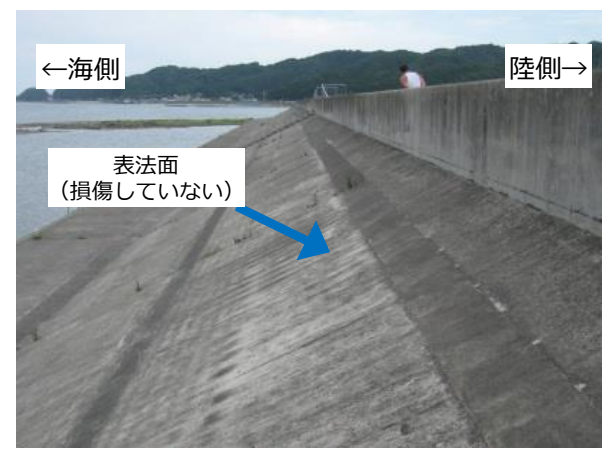

(a) 堤防表法側の被災状況

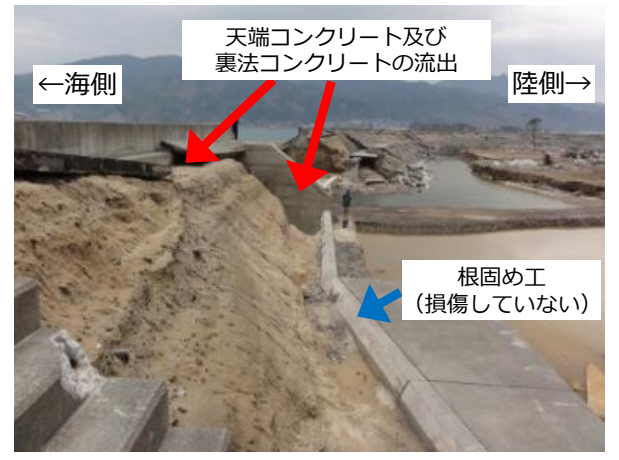

(b) 堤防裹法側の被災状況（その1）

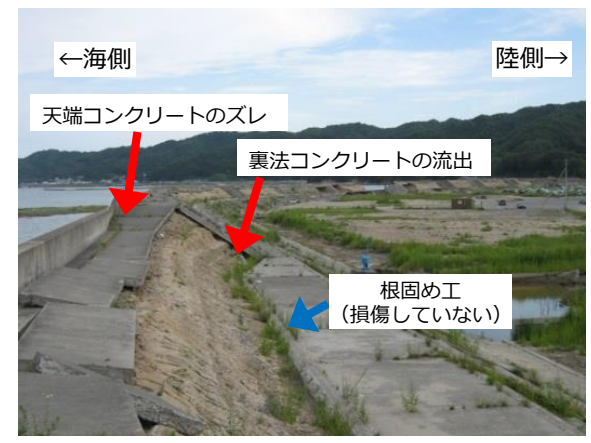

(c) 堤防裏法側の被災状況（その2）

写真-6 岩手県宮古市宮古湾における三面 張り海岸の損傷状況

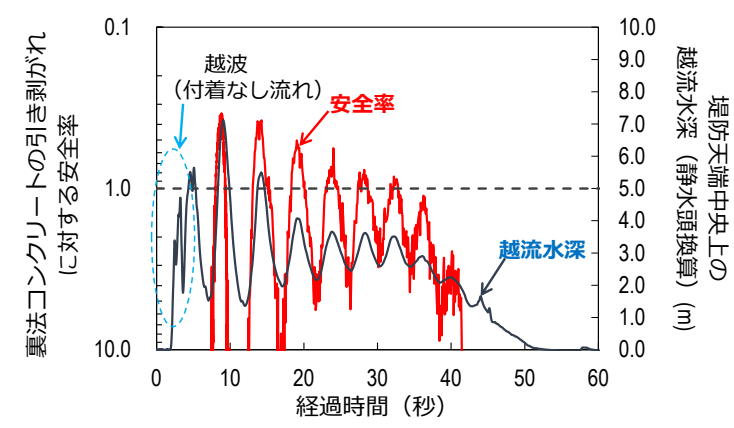

図-4 堤防天端中央上における越流水深及び揚力による 裏法コンクリートの引き剥がれに対する安全率
あり，裏法コンクリートを引き剥がす力として作用する。

図-4に裏法コンクリート（厚み $0.25 \mathrm{~m}$ ，長さ $3.2 \mathrm{~m}$, 比 重2.3）の引き剥がれに対する安全率の変化を示す。引 き剥がれに対する安全率は，裏法コンクリート下端を回 転端としたときの負圧による起動モーメントと，コンク リート自重による抵抗モーメントの比である7). 越流水 深の増加に伴って負圧が大きくなるので，安全率が低下 する. 越流水深と安全率の変動を見ると，大体 $4.0 \sim 5.0 \mathrm{~m}$

（静水頭換算）を上回った時点で安全率1.0を下回った. 負圧によって裏法コンクリートが一旦引き剥がされると, 目地劣化モデルと同様な崩壊過程を辿ることがわかった。 以上のことから，三面張り堤防は，被覆コンクリート が一部でも流出してしまうと，盛土の侵食によって崩壊 する危険性が一気に高まることがわかった。

\section{4. 被災事例との比較}

写真-6は岩手県宮古市宮古湾における海岸堤防の被 災状況である．写真-6(a)は堤防表法側の壁体の状況であ る. 堤防表法側には目立った損傷は見られなかった。写 真-6(b)，(c)は堤防裹法側の状況である．董法尻に設置さ れた根固め工に滑動や流出は見られなかった。これは, 背後地盤が深くまで洗堀されなかったため，根固め工に 対する受働土圧が確保され，滑動が抑制されたためだと 考えられる. 一方，天端コンクリートや裏法コンクリー 卜は，ズレや流出が生じていた．被災後の状況のみで原 因を特定することはできないが，先述の実験結果に示し たように，根固め工が変位しない条件でも，(1)地震力で 損傷した目地部の遮水性の低下や，(2)深い越流水深によ る揚力が発生すると，裏法コンクリートの流出が生じた 可能性が高いと考えられる.

\section{5. 考察及び結論}

盛土表面に被覆コンクリートを設置した三面張り海岸 堤防を対象とした縮尺 $1 / 15 の$ 水理実験を実施した。その 結果，堤防背後の裹法尻地盤が洗堀を受けない条件でも， 地震による目地部の開きなどで目地部の遮水性が低下す ると，裏法コンクリートに越流水が回り込み，泥圧によ って裏法コンクリートが押し出されることがわかった. この場合，越流水深の規模よりもむしろ裏法コンクリー 卜背面に流入する越流水が問題であることがわかった. 一方，目地部が健全な場合は，小規模な越流に対しては 一定程度の耐久性を有するが，越流水深が約 $5.0 \mathrm{~m}$ 以上に なると，揚力によって裏法コンクリートが引き剥がされ ることがわかった。

以上のことから，設計の規模を超える津波に対して粘 り強さを確保するには，堤防の而震化や長寿命化によっ 
て目地部の劣化を抑制するとともに，被覆コンクリート を盛土に定着して引き剥がれにくくすることが重要であ ることが分かった．また地震等によって多少の損傷が生 じた状態でも，堤防の耐侵食性が大きく損なわれない工 夫を導入することが重要であると考えられる．具体的に は，目地部の多少の開きや不陸などの損傷が構造上の弱 点とならないような被覆ブロックの噛み合わせ5)や連結 構造, さらには多少の越流水が被覆コンクリート背面に 流入しても吸い出されない盛土材などが有効な対策にな ると考えられる.

謝辞 : 本研究は, 復興庁・農林水産庁食料生産地域再生 のための先端技術展開事業による補助を受けました.

\section{参考文献}

1) 海岸保全施設技術研究会編，海岸保全施設の技術上 の基準・同解説:平成 16 年 6 月, 2004

2) 東日本大震災合同調查報告書編集委員会，東日本大 震災合同報告書 共通編 2 「津波の特性と被害」： pp.221-246, 2014.
3) 中央防災会議, 東北地方太平洋沖地震を教訓とした 地震・津波対策に関する専門調査会中間とりまとめ ～今後の津波防災対策の基本的考方方について〜， 平成 23 年 6 月 26 日, , p.10, 2011.

4) 水谷 将，今村文彦: 構造物に作用する段波波力の実 験，土木学会論文集 B2(海岸工学), Vol. 47, No.2, pp.946-950, 2000.

5) 国土交通省国土技術政策総合研究所河川研究部: 粘り 強く効果を発揮する海岸堤防の構造検討(第 1 報), No. 1, 平成 24 年 5 月 14 日, 2012.

6) 松島健一, 三島尚人, 桐 博英, 中 達雄: 海岸堤防 に作用する衝突波力の発生機構に関する実験的考察, 土木学会論文集 B2(海岸工学), Vol. 71, No.2, 投稿中, 2015.

7) 松島健一, 大井邦昭, 毛利栄征, 龍岡文夫, 平井卓, 桐博英: 越流津波時の揚力による防潮堤法肩ブロック の引き剥がれとその対策, 土木学会論文集 B2(海岸工 学), Vol. 70, No. 2, pp.1001-1006, 2014.

(2015.3.18 受付)

\section{FAILURE MECHANISM OF CONVENTIONAL DIKE UNDER OVERFLOW TSUNAMI}

\section{Kenichi MATSUSHIMA, Naoto MISHIMA Hirohide KIRI and Tatsuo NAKA}

In order to elucidate the failure mechanism of damaged coastal dikes by the Great East Japan Earthquake tsunami, hydraulic overflow tests were carried out with using dike prototypes that replicated reduced impermeable condition of joint concrete due to earthquake on one hand and that of which did not in the other. As a result, overflow water intruded under the land-side cover concrete, pushing it out due to the pressure of muddy water with the case of deteriorated impermeability even though the intensity of overflow was relatively small. Likewise, it was found that the land-side cover concrete was torn off by uplift force when overflow depth exceeded about $5.0 \mathrm{~m}$. Thus, given the damaged condition of joint concrete, countermeasures to prevent concretes from tearing off, as well as to protect from getting soggy condition of backfill were necessary to ensure further durability. 